\title{
3G, 4G, 5G CELL TOWER AND THEIR EFFECTS ON HUMAN HEALTH: CASE STUDY OF THE BRAIN
}

\author{
Dr. Yekeen, Olajide Olasoji \\ Department of Electrical Electronics \\ Federal University of Technology \\ Akure, Ondo, Nigeria
}

\begin{abstract}
Everyday activities of human life is full of exposure to electromagnetic radiation either from mobile cell towers, mobile phones, radio station transmitters as well as the electric transmission lines. Radio frequency electromagnetic radiation from mobile phones is classified as non-ionization radiation but the fact still remains that this radiation has effect on human health. Radio frequency (RF) electromagnetic radiation is use in mobile phone to transmit information between handsets and base stations either in analog or digital form. Mobile phone system uses different signals (different frequency bands and information coding methods) for their transmission. In recent time it has been said that there will be transition from 3G\&4G to 5G in view of this, the study will show the effect of the radiation as related to Specific Absorption Rate of mobile phones as well as the frequency of operation and how this affects human health.
\end{abstract}

Keywords- Electromagnetic, Radio-Frequency, Transmission, Coding, Non-Ionization, Radiation, Specific Absorption Rate

\section{INTRODUCTION}

A vast increase in mobile cell phones subscriber has generate a lot of public concern especially the $5 \mathrm{G}$ network about the possible or related adverse effect in both human, animals and all living organism as a result of exposure to this radiation from mobile phone cell tower or cell phone itself.

Ayeni et al, 2011 described such radiation from cell tower and mobile phones as a non-ionization radiation. Shivers et al, 1987 examined the effect of magnetic resonance imaging upon the rat brain with more research showing that rabbit exposed to

\author{
Adefela Adekunle Nicholas \\ Centre for Renewable Energy Technology \\ Federal University of Technology \\ Akure, Ondo, Nigeria
}

radiation became blind after 100days of exposure. In 2019 a female rabbit was exposed to radiation from mobile phone by Dr Y.O. Olasoji and A.N Adefela with SAR value of $1.6 \mathrm{~W} / \mathrm{kg}$ operating at $900 \mathrm{MHz}$ for over 120days which eventually increases the temperature of the rabbit fallopian tube which destroys the babies produced by the rabbit. The voluntary exposure of the brain to radiation from mobile cell phones mostly by $1 / 4$ subscribers has been called the largest human biological experiment ever (Salford et al. 2011).

When using mobile phones, electromagnetic wave is transferred to the body which causes health problems especially at the place near ear skull region where they are known to affect neuron because all cell towers and mobile phones radiate or emits radio frequency radiation during signal propagation which makes it extremely dangerous to human, animals and plants. Transition plan made to move from both $3 \mathrm{G}$ and $4 \mathrm{G}$ to $5 \mathrm{G}$ across globe has generated more concern about the health effect which will be by this transition on human health. In less than few month every villages, town, cities, countries and the entire globe will operate mobile communication system using 5G technology and as a result of this every existing mobile phone tower will be linked up with the mini $5 \mathrm{G}$ cell tower in our neighborhood and cities both beside and on-top of our houses including the street light poles. Since the $5 \mathrm{G}$ is designed to operates on ultra high frequency, ultra high intensity, millimeter wave-length and high penetration power resulting into spontaneous disintegration of quantum energy at high rate and since the frequency is of high the wave length is small which makes it travel less and as a result of this many and more mini cell towers will be installed at few meters to each other making all environment be more dense populated with electromagnetic radiation. 


\section{LITERATURE REVIEW}

Various controlled scientific studies on $2 \mathrm{G}, 3 \mathrm{G}$ and $4 \mathrm{G}$ technologies show that stress, brain damage, sperm and testicular damage, neuropsychiatric effects, fatigue, dizziness, oedema, change in electrical impulse in human brain, cellular DNA damage can all occur in humans as a result of exposure to electromagnetic from mobile phone. Seybold, 2005 study human biological tissue as a lossy dielectric materials with permeability equal to free space permeability $\left(\mu=\mu_{\mathrm{o}}\right)$ and conductivity that depends on tissue properties and signal frequency. Pelvig et al, 2008 sees human brain as the most complex organ in a vertebrate body in a typical human, the cerebral cortex is estimated to contain 1533 billion neuron each connected by synapses.

Sarah Drieben of the research center for electromagnetic environment compatibility at Germany's university of Aachen show a strong connection between radiofrequency field of an existing standards and cancer in rats. In a test carried out in a mice exposed to EMFs for nine (9) hours a day for a period of 2 years brings about drastic changes in the nervous system of the mice including the brain, heart and testes all conducted using 3G network. Epidemiological evidence was subsequently reviewed and incorporate in a metal-analysis by Rooli et al concluded that overall epidemiological evidence does not suggest increased brain or salivary gland turmor risk with mobile phone use although the authors admitted that some uncertainty remains regarding long latency periods ( $>15$ years) rare brain tumor sub types with mobile usage during childhood.

\section{METHODOLOGY}

The method used in this research work is based on the comparison between Specific Absorption Rate and the average frequency of operation of mobile carrier. This is done by adopting some formula such as Maxwell equation $\mathrm{SAR}=\frac{\partial\left(E^{2}\right)}{2 p} \ldots \ldots 1$. Where $\mathrm{E}$ is the electric field intensity, where $p$ is the tissue density and $\partial$ is the tissue conductivity where power density is given $\mathrm{p}$ as $\frac{\partial\left(E^{2)}\right.}{2} \ldots . .2$. Since most mobile phones are placed close to the head we consider the brain tissues and also some tissues in the body using radiofrequency penetrating dept formula as $\delta=$ $\frac{1}{\sqrt{\pi \mu \partial f}} \ldots . . .3$, where $\delta$ the depth of penetration, $\mu$ is the permeability of human tissue which is equal to permeability of free space $=4 \pi \times 10^{-7} \mathrm{Hm}^{-1}$.
Power density of the GSM mobile phone is given as $\mathrm{P}_{\mathrm{d}=} \frac{E R P}{4 \pi(d+\delta)^{2}}=\frac{P_{t} G_{t}}{4 \pi(d+\delta)} \ldots . .4$ where $\mathrm{p}_{\mathrm{t}}$ is the average power transmitted by phone, $G_{t}$ is the unity (1) gain of the antenna since the antenna is always transmitting the signal in a single direction towards the head while $d$ is the distance of the antenna to the head depending on the user but assumption in this research work is based on the average of the distance between $0.5 \mathrm{~cm}-2 \mathrm{~cm}$ with an average of $1.25 \mathrm{~cm} . \mathrm{P}_{\mathrm{t}}$ is giving as one eight of the average power radiated by the GSM which is $0.125 \times 1.6 \mathrm{~W} / \mathrm{kg}=0.2 \mathrm{~W}$. The induced electric field and magnetic field exert pressure on the tissue around it and interact with the materials. Since the velocity of propagation in human tissue is lower than that of free space we have it to be $3 \times 108 \mathrm{~m} / \mathrm{s}$ while the impedance of human tissue is giving as $\eta=\eta_{\mathrm{o}} \sqrt{ } \frac{\mu r}{\varepsilon r} \ldots \ldots . . . .5$

Where $\eta_{o}=377 \mathrm{ohms}$. Relating power density $P_{d}$, the impedance of the medium ( $\eta$ ), the electric field (E) and the magnetic field $(\mathrm{H})$ we have $\mathrm{Pd}=\left(\mathrm{E}^{2} \div \eta\right)=$ $\mathrm{H}^{2} \eta \ldots \ldots .6$.

Since the body is a weak magnetic material therefore $\mu_{\mathrm{r}}=1$ and the relative permeability of the brain is 1 .

Table 1: below show the permittivity, conductivity and dielectric properties of human tissue with different frequency range.

\begin{tabular}{c|c|c|c|c|c|c}
\multirow{2}{*}{ Layer } & \multicolumn{3}{|c|}{ Relative permittivity } & \multicolumn{3}{c}{ Conductivity (S/m) } \\
\cline { 2 - 7 } & $900 \mathrm{MHz}$ & $1800 \mathrm{MHz}$ & $2.4 \mathrm{GHz}$ & $900 \mathrm{MHz}$ & $1800 \mathrm{MHz}$ & $2.4 \mathrm{GHz}$ \\
\hline Skin & 41.4 & 38.9 & 38.1 & 0.87 & 1.18 & 1.44 \\
\hline Fat & 5.46 & 5.34 & 5.29 & 0.051 & 0.078 & 0.102 \\
\hline Bone & 12.45 & 11.8 & 11.41 & 0.14 & 0.28 & 0.385 \\
\hline Dura & 44.4 & 42.9 & 42.1 & 0.96 & 1.32 & 1.64 \\
\hline CSF & 68.7 & 67.2 & 66.3 & 2.41 & 2.92 & 3.41 \\
\hline Brain & 45.8 & 43.5 & 42.6 & 0.77 & 1.15 & 1.48
\end{tabular}

Source: https://www.researchgate.

Table 2 below show the electrical properties of human brain tissue from $5 \mathrm{GHz}-100 \mathrm{GHz}$ 


\begin{tabular}{|l|l|l|l|l|l|l|}
\hline $\begin{array}{l}\text { Frequency } \\
\text { GHz }\end{array}$ & \multicolumn{5}{l}{ Dry skin } & \multicolumn{3}{l|}{ Wet skin } \\
\hline & $\sigma(\mathrm{S} / \mathrm{m})$ & $\varepsilon_{\mathrm{r}}$ & $d(\mathrm{~mm})$ & $\sigma(\mathrm{S} / \mathrm{m})$ & $\varepsilon_{\mathrm{r}}$ & $d(\mathrm{~mm})$ \\
\hline 5 & 3.06 & 35.77 & 10.49 & 3.57 & 39.61 & 9.49 \\
\hline 10 & 8.01 & 31.29 & 3.80 & 8.95 & 33.53 & 3.53 \\
\hline 14.5 & 13.27 & 26.88 & 2.16 & 14.08 & 28.62 & 2.10 \\
\hline 20 & 19.22 & 21.96 & 1.38 & 19.71 & 23.77 & 1.39 \\
\hline 30 & 27.10 & 15.51 & 0.85 & 27.52 & 17.74 & 0.88 \\
\hline 31 & 27.69 & 15.030 & 0.82 & 28.151 & 17.294 & 0.85 \\
\hline 40 & 31.80 & 11.69 & 0.65 & 32.87 & 14.09 & 0.67 \\
\hline 45 & 33.94 & 10.40 & 0.59 & 34.94 & 12.81 & 0.605 \\
\hline 50 & 34.62 & 9.40 & 0.54 & 36.69 & 11.77 & 0.56 \\
\hline 60 & 36.40 & 7.98 & 0.48 & 39.52 & 10.22 & 0.49 \\
\hline 70 & 37.58 & 7.04 & 0.43 & 41.71 & 9.12 & 0.43 \\
\hline 80 & 38.40 & 6.40 & 0.40 & 43.46 & 8.32 & 0.40 \\
\hline 90 & 38.99 & 5.94 & 0.38 & 44.90 & 7.72 & 0.37 \\
\hline 100 & 39.43 & 5.60 & 0.36 & 46.12 & 7.25 & 0.35 \\
\hline
\end{tabular}

Source: : https://www.researchgate.

\section{RESULTS AND DISCUSSION}

Table above shows the tissue properties of human with $3 \mathrm{G}$ and $4 \mathrm{G}$ networks with frequency of $900 \mathrm{MHz}$ and $1800 \mathrm{MHz}$ and the future $5 \mathrm{G}$ networks with a frequency range of $60 \mathrm{GHz}-100 \mathrm{GHz}$. Since the mobile phone is held close to the head our focus is mainly the brain. Recall every mobile communication has both uplink and downlink so for GSM-900MHz, the medium link is $942.5 \mathrm{MHz}$ and for $1800 \mathrm{MHz}$ the medium link is $1842.5 \mathrm{MHz}$. Calculating the depth of penetration we use equation...3

$\delta=\frac{1}{\sqrt{ } \pi \mu \partial f}$

\section{A) Dept of penetration}

At $900 \mathrm{MHz}$ the depth of penetration is $\delta=$ $\frac{1}{\sqrt{3.142 \times 4 \times 3.142 \times 10^{-7} \times 0.77 \times 942.5 \times 10^{6}}}$

$=0.01868 \mathrm{~m}$

At $1800 \mathrm{MHz}$ the depth of penetration is

$\delta=\frac{1}{\sqrt{3.142 \times 4 \times 3.142 \times 10^{-7} \times 1.15 \times 1842.5 \times 10^{6}}}$

$=0.01093 \mathrm{~m}$

At $60 \mathrm{GHz}$ the depth of penetration is

$\delta$

$$
\begin{aligned}
& =\frac{1}{\sqrt{3.142 \times 4 \times 3.142 \times 10^{-7} \times 36.4 \times 62.5 \times 10^{9}}} \\
& =0.000334 \mathrm{~m}
\end{aligned}
$$

Calculating the power density of the signal at $900 \mathrm{MHz}, 1800 \mathrm{MHz}$ and $60 \mathrm{GHz}$ using equation 4 above $=\frac{P_{t} G_{t}}{4 \pi(d+\delta)}$ assuming the specific absorption rate $\mathrm{f}$ the mobile phone is $1.6 \mathrm{~W} / \mathrm{kg}$ to $10 \mathrm{gram}$ of tissue and since only 0.125 of the power absorb by the body therefore we have $\mathrm{P}_{\mathrm{t}}=0.125 \times 1.6 \mathrm{~W} / \mathrm{kg}=0.2 \mathrm{~W} / \mathrm{kg}$ where $G_{t=}$ Antenna gain is 1 therefore the power density at $900 \mathrm{MHz}$ will be $=\frac{0.2 \times 1}{4 \times 3.142(0.0125+0.01868)}=$ $16.37 \mathrm{~W} / \mathrm{m}^{2}$

At $1800 \mathrm{MHz}$ power density will be

$\frac{0.2 \times 1}{4 \times 3.142(0.0125+0.01093)}=28.99 \mathrm{~W} / \mathrm{m}^{2}$

At $60 \mathrm{GHz}$ power density will be

$\frac{0.2 \times 1}{4 \times 3.142(0.0125+0.000334)}=96.61 \mathrm{~W} / \mathrm{m}^{2}$

The electric field induced in the brain is calculated by calculating the impedance at each frequency level using equation 5

\section{B) Impedance}

$\mathrm{\eta}=\mathrm{\eta}_{\mathrm{o}} \sqrt{\frac{\mu r}{\varepsilon r}}$

For $900 \mathrm{MHz}$ the impedance is

$377 \sqrt{ } 1 \div 45.8=55.71 \mathrm{ohms}$

At $1800 \mathrm{MHZ}$ the impedance is

$377 \sqrt{ } 1 \div 43.5=57.16 \mathrm{ohms}$

At $60 \mathrm{GHz}$ the impedance is

$377 \sqrt{ } 1 \div 7.98=133.46 \mathrm{ohms}$

\section{C) Induce electric field}

The induced electric field is calculated using the equation $E=\sqrt{ }\left(P_{d} \times \eta\right)$

At $900 \mathrm{MHz} \mathbf{E}=\sqrt{ } 16.37 \times 55.71=30.198 \mathrm{~V} / \mathrm{m}$

At $1800 \mathrm{MHz} \mathbf{E}=\sqrt{ } 28.99 \times 57.16=40.71 \mathrm{~V} / \mathrm{m}$

At $60 \mathrm{GHz} \mathbf{E}=\sqrt{ } 96.61 \times 133.46=113.55 \mathrm{~V} / \mathrm{m}$ 


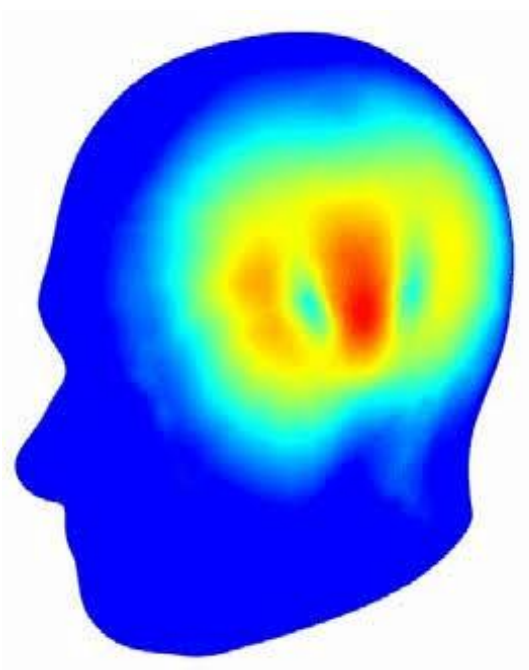

$7 \mathrm{~V} / \mathrm{m}$ $6,5 \mathrm{~V} / \mathrm{m}$ $6 \mathrm{~V} / \mathrm{m}$ $5,5 \mathrm{~V} / \mathrm{m}$ $5,0 \mathrm{~V} / \mathrm{m}$ $4,5 \mathrm{~V} / \mathrm{m}$ $4 \mathrm{~V} / \mathrm{m}$ $3,5 \mathrm{~V} / \mathrm{m}$ $3 \mathrm{~V} / \mathrm{m}$ $2,5 \mathrm{~V} / \mathrm{m}$ $2 \mathrm{~V} / \mathrm{m}$ $1,5 \mathrm{~V} / \mathrm{m}$ $1 \mathrm{~V} / \mathrm{m}$
Source: http the image above shows mobile phone power at $0.8 \mathrm{~W}$ with a specific absorption rate of $0.6 \mathrm{~W} / \mathrm{kg}$ with maximum induced electric field at $7 \mathrm{~V} / \mathrm{m}$ at $900 \mathrm{MHz}$ as compared to our calculated value.

\section{OBSERVATION}

From the above result it is observed that an increase in frequency with a mobile phone of high SAR value increases the power density of the signal as well as the impedance of the signal which in-turn increases the induce electric field near the tissue. Since power density increases with increase in frequency more heat are generated which in-turn heated up the cells around the region and damaged the cells and tissues around there. Also the induced electric field increases with increase in frequency thereby raising the temperature of the surrounding which in-turn increases the temperature around the cells and tissues.

\section{RECOMMENDATION}

From the above study it is recommended that the frequency of operation of the fifth generation (5G) should be reduced to minimal frequency so as to reduce the power density as well as to reduce the induced electric field. The specific absorption rate of mobile phone sold in the market must be reduced to values to $0.6 \mathrm{~W} / \mathrm{kg}$ which will make subscribers to be as save as possible. More so mobile phone subscriber should be advice to make use of quantum shield, wired headset when making calls and also subscriber should use text messages in replacement of long calls.

\section{CONCLUSION}

From the studies we saw that the GSM we are using can have effect on surrounding of our brain but not something that we can see. Over long period of time the effect of the radiation begins to show up as human is ageing. In conclusion we suggest a drastic reduction in the frequency of operation of the $5^{\text {th }}$ generation mobile network or be suspended until further review.

\section{ACKNOWLEDGEMENT}

The author and the co-author sincerely acknowledge and appreciate the reviewers for their precious time taking in reviewing this paper.

\section{REFERENCES}

1. Abdelati, and Mohammed, (2005). Electromagnetic Radiation from Mobile Base stations at Gaza, Journal of the Islamic University of Gaza (Natural Sciences Series) Vol.13 (2), (pp.129 - 146).

2. Adegoke, A.S.; Babalola, I.T.; and Balogun. (2008)'. Performance Evaluation of GSM mobile system in Nigeria, Pacific Journal of Science and Technology. Vol. 9(2), (pp.1-6).

3. Ayeni, A. A.; Braimoh, K.T.; Ayeni, O. B. (2011). Effect of GSM Phone Radiation on Human Pulse Rate (Heartbeat Rate).Vol. 2(11), (pp. 1 - 8).

4. Bernardi, P., Cavagnaro, M., Pisa, S., and Piuzzi, E. (2001)'. Power Absorption and Temperature Elevations Induced in the Human Head by a DualBand Monopole-Helix Antenna Phone," IEEE Transactions on Microwave Theory Tech. Vol. 49(12), (Pp. 2539 - 2546).

5. Ellis KJ. (2000). Human body composition in vivo methods- Physiol Rev 80, (pg.649-680).

6. Ibrani M., Ahma L., Hamiti E., Haxhibeqiri J. (2011)'. Derivation of electromagnetic properties of child biological tissues at radio frequencies- Progress in Electromagnetics Res Lett 25, (pg.87-100).

7. Pelvig, D.P.; Pakkenberg, H., Stark, A.K.; Pakkenberg, B. (2008). Neocortical glial cell numbers in human brains - Neurobiology of Aging Vol.29 (11), (pp. 1754 - 1762).

8. Peyman A., Rezazadeh A., Gabriel C. (2002)'. Changes in the dielectric properties of rat tissue as a 


\section{International Journal of Engineering Applied Sciences and Technology, 2020 \\ Vol. 5, Issue 5, ISSN No. 2455-2143, Pages 20-24 \\ Published Online September 2020 in IJEAST (http://www.ijeast.com)}

function of age at microwave frequencies. Phys Med Biol 47, (Pg.3-4).

9. Peyman A., Gabriel C. (2010)'. Cole-Cole parameters for the dielectric properties of porcine tissues as a function of age at microwave frequencies. Phys Med Biol 55:N413-N419.

10. Parise, M. (2011). On the use of cloverleaf coils to induce therapeutic heating in tissues. Journal of Electromagnetic Waves and Applications, Vol. 25(11-12), (pp.1667 - 1677).

11. Salford, L.G.; Brun, A.E.; Eberhardt, J.L.; Malmgren, L. and Persson B. R.R (2003). Nerve Cell Damage in Mammalian Brain after Exposure to Microwaves from GSM Mobile Phones. Vol. 111(7), (pp.1 - 3).

12. Schirmacher, A., Winters, S., Fischer, S. (2000)'. Electromagnetic fields $(1.8 \mathrm{GHz})$ increase the permeability to sucrose of the blood-brain barrier in vitro. Bioelectromagnetics Vol. 21, (pp. 338 - 345).

13. Schmid, G., Neubauer G., Mazal PR. (2003). Dielectric properties of human brain tissue measured less than $10 \mathrm{~h}$ postmortem at frequencies from 800 to $2450 \mathrm{MHz}$. Bioelectromagnetics 24:6

14. Seybold., and John S. (2005)'. Introduction to RF Propagation, John Wiley \& Sons, Inc, New Jersey, First Edition, 2005.

15. Shivers, R., Kavaliers, M., Teskey, G., Prato, F. and Pelletier, R. (1987)'. Magnetic resonance imaging temporarily alters blood brain barrier in the rat. Neurosci Lett, Vol. 76, (pp. 25 - 31).

16. Thomas, J.R.; Finch, E.D.; Fulk, D.W.; and Burch, L.S. (1975). Biological Effects of Nonionizing Radiation, P. Tyler, ed., Ann. New York, Academic Science. Vol. 247, (Pg.410).

17. Wachtel, H., Seaman, R., Tyler, P. and Joines, W. (1975). Biological Effects of Non-ionizing Radiation. New York, Acad. Sci. Vol. 247, (pg.46). 